\title{
Service Provision in Rural Water Supplies: Analysis of Four Community-Based Systems in Colombia
}

Isabel Domínguez Rivera*

Edgar Ricardo Oviedo-Ocaña**

Inés Restrepo-Tarquino***

doi:I0.III44/Javeriana.cdri3-77.sprw

Recibido: 2015-II-02 Aprobado: 2016-06-08 Disponible en línea: 2016-06-15

Como citar este artículo: Domínguez Rivera, I., Oviedo-Ocaña, E. R., y Restrepo-Tarquino, I. (2016) Service provision in rural water supplies: analysis of four community-based systems in Colombia. Cuadernos de Desarrollo Rural, 13 (77), I17-140. http://dx.doi.org/10.11144/Javeriana.cdri3-77.sprw

\footnotetext{
* Profesora auxiliar, Universidad Industrial de Santander. Escuela de Ingeniería Civil. Colombia. Correo electrónico: isabeldr@uis.edu.co http://orcid.org/0000-0002-7677-2731.

** Profesor asistente, Universidad Industrial de Santander, Escuela de Ingeniería Civil. Colombia. Correo electrónico: eroviedo@uis.edu.co.

http://orcid.org/0000-0002-8970-7322

*** Profesora asociada, Instituto Cinara, Universidad del Valle. Colombia. Correo electrónico: ines. restrepo@correounivalle.edu.co

http://orcid.org/0000-0003-4705-2062
} 


\begin{abstract}
Community management is the tendency to provide water to rural areas worldwide. Despite the diversity of rural communities and their water supplies, policies tend to be uniform, failing to be effective. Four rural water supplies in the Colombian Andes were studied combining quantitative and qualitative methods. Aspects of infrastructure, training of human resources, revenue collection, water quality and postconstruction support were studied. The study provides evidence on the need to design policies and programs that consider rural diversity to help communal water organizations to provide sustainable services.
\end{abstract}

Keywords:

community management; rural water systems, post-construction support; water quality; Colombia

\title{
Prestación del servicio en los suministros de agua rurales: análisis de cuatro sistemas comunitarios en Colombia
}

\section{Resumen}

La administración comunitaria es la tendencia mundial para el suministro de agua a las áreas rurales; sin embargo, pese a la diversidad de comunidades rurales y suministros de agua, las políticas tienden a la uniformidad, por lo que no resultan efectivas. Se estudiaron cuatro suministros de agua en los Andes colombianos, por medio de una combinación de métodos cuantitativos y cualitativos, observando aspectos de la infraestructura, capacitación en recursos humanos, recaudo de ingresos, calidad del agua y soporte posterior a la construcción. El estudio muestra evidencias de cómo resulta necesario diseñar políticas y programas que tengan en cuenta la diversidad rural, para ayudar a las organizaciones comunitarias del agua a proporcionar servicios sostenibles.

\section{Palabras clave:}

administración comunitaria; sistemas de agua rurales; soporte posterior a la construcción; calidad del agua; Colombia 


\section{Introduction}

In the world, there is a welfare urban-rural gap which demands urgent interventions (Bambra et al., 2010), and extends to water and sanitation services (Bain, Wright, Christenson, \& Bartram, 20I4; World Health Organization [wHo] \& United Nations Children's Fund [Unicef], 20I4). While the Millennium Development Goals (MDGs) represented a significant progress on access to water, increasing coverage from 76 to $88 \%$ between 1990 and 20I2, it is recognized this progress was uneven, and further interventions in rural areas are required to ensure equity (wHO \& Unicef, 20I4). Even when rural people have access to an "improved water source" (wHO, 2OI2a), water is not necessarily safe (Bain, Cronk, Wright, et al., 20I4; Bain, Wright, Christenson, \& Bartram, 20I4; Hunter, Pond, Jagals, \& Cameron, 2009), and often rural systems present technological, financial, and operational deficiencies that prevent people to enjoy sustainable services and good health (Kayser, Kayser, Moomaw, Portillo, \& Griffiths, 2014; Smits, Rojas, \& Tamayo, 2013).

Due to the difficulties of governments in developing countries to provide services in rural communities (Foster, 2013; Harvey \& Reed, 2007), and the lack of attractive financial returns for private providers to operate in these areas (Bakker, 2007), since the I990s community management has been the model which governments and donors promote for the provision of water services in the rural world (de San Miguel, Flores, Vilchis, Tovar, \& Pedraza, 2015; Harvey \& Reed, 2007; Moriarty, Smits, Butterworth, \& Franceys, 2013; Smits et al., 2013).

The fundamentals of the community management concept are based on the principles of the theory of common pool resources and collective action, which argues that individuals voluntarily organize themselves to obtain benefits from the use of natural resources, and for that they create and enforce rules to manage them (Ostrom, 2000). Other influences on the model come from neoliberal agendas that consider water as a commodity for which access must be paid (Bakker, 2007). Some authors who criticize community management in water services in rural areas believe that these two influences are incompatible and that this may be the main reason why the model is not completely successful (van den Broek \& Brown, 2015).

Under community management in water service provision, communities are expected by government institutions or donors to constitute organizations for operating and maintaining the services, collect water tariffs, and conduct repairs, among others (Harvey \& Reed, 2007; Mandara, Butijn, \& Niehof, 2013). Despite the fact that, these schemes have contributed to significant progress in water access worldwide (e.g. to increase coverage and service levels in rural areas) (Moriarty et al., 2013; Whittington 
et al., 2009), community organizations struggle with many aspects of the service, including: aging of infrastructure, water quality monitoring, financial management (Kayser et al., 20I4), lack of users' participation and funds for operation and maintenance (van den Broek \& Brown, 2015). These aspects are particularly complex in rural areas due to the nature of water services (e.g. high capital and replacement costs), and the characteristics of rural settings (e.g. scattering, low density, poverty, low availability of trained personnel) (Wedgworth et al., 20I4).

The limitations of community management for water service provision in rural areas have led to the recognition that these organizations demand ongoing post-construction support (Foster, 20I3; Harvey \& Reed, 2007; Kayser et al., 20I4; Mandara et al., 2013; Moriarty et al., 2013; Whittington et al., 2009). However, there are countries which still lack of policies or formal institutional structures to back these organizations (Harvey \& Reed, 2007; Kayser et al., 20I4; Whittington et al., 2009). Other authors, without proposing an alternative, suggest that the request for postconstruction support made by practitioners and the academy is an indication that the community management model is not working (van den Broek \& Brown, 20I5).

There is a large volume of research on different dimensions of access to water in rural settings. There are studies dealing with the lack of coverage (Bain, Wright, et al., 20I4); the deficient water quality or safety (Bain, Cronk, Hossain, et al., 20I4; Bain, Cronk, Wright, et al., 20I4; Heitzinger et al., 20I5; Macharia, Yillia, Muia, Byamukama, \& Kreuzinger, 2015); advantages and limitations of community management (Bernal, Rivas, \& Pena, 20I4; de San Miguel et al., 2015; Harvey \& Reed, 2007; Mandara et al., 2013), and models for post-construction or external support (Davis et al., 2008; Kayser et al., 2014; Smits et al., 2013; Whittington et al., 2009). However, to our knowledge, limited studies address this issue by integrating these different dimensions. Therefore, this research involves the study of managerial, technical, water quality and post-construction support aspects together, in four rural water supply systems (WSS). The four systems were community managed with differences on their levels of resources, capabilities, and compliance with legal, financial, technical and managerial standards of service provision but with the similarity of lacking of external support. The research aims to provide evidence on the diversity, complexity and challenges these systems face. This evidence can contribute to design policies and strategies required to ensure safety and sustainable water services that consider diversity of rural settings, as required by the United Nations post-20I5 development agenda (WHO \& Unicef, 20I4). 


\section{Methodology}

A case study, with a multiple-case design was used (Yin, 20r4). The analysis unit was communal water supply systems (WSS), where four systems were studied. The systems served people from a scattered rural area in a municipality in the Colombian Andes and were identified as: WSS (I6 subscribers), WSS 2 subscribers), WSS 3 ( 83 subscribers), and WSS 4 (560 subscribers). The infrastructure of the four systems consisted of: intake, grit chamber, transmission pipe, storage tank, distribution network, and household connections. There was no water treatment, except in WSS ${ }_{4}$, which had chlorine disinfection. While WSS to WSS , provided water to scattered households, WSS served scattered and nucleated households. Qualitative and quantitative methods were used (mixed methods). Qualitative methods involved semi-structured interviews with water managers and inspections to communal water systems, and quantitative methods included sampling and analysis of water quality. The adoption of the mixed methods approach contributes to reduce errors, bias and a guard against some threats to validity and reliability (Robson, 20II).

\section{I. Study area}

The systems provided water to around $60 \%$ of the population from io rural settlements in the municipality of Riofrío, Valle del Cauca, Colombia. Figure i shows the study area and the location of the settlements served by the WSSs studied. The territory is mountainous located on the Andes range, with altitudes between 1000 and 1900 m (Corporación Autónoma Regional del Valle del Cauca [CVC], 20I2). A basic socioeconomic characterization was carried out within this research. Systems' subscribers were families with an average of three members. The main demographic characteristics were low fecundity, a higher male population, and the preponderance of people about 40 years. Regarding education, access decreased from 100\% coverage for children enrolled in primary to $22 \%$ for the young between I8 to 24 years. Only $16 \%$ of the population completed secondary school. $17 \%$ of homes were built with inadequate materials, mainly lack of floor, and $95 \%$ of households had access to improved sanitation. Peoplés livelihoods were dependent on small scale coffee farming and livestock, which provided income levels generally below the national legal monthly minimum wage (246 USD in 2013, considering an exchange range of $2400 \mathrm{COP} / \mathrm{I}$ USD). A more detailed socioeconomic characterization of the studied area can be found in Dominguez (20I4). 
The study area was selected because a Non-Governmental Organization (NGO), the Departmental Committee of Coffee Growers (DCC), developed a project with interventions on natural resources conservation and farmers' wellbeing in this region. The study of wSSs was considered an integral part of the wellbeing of these communities. The selection of this location for intervention by DCC considered several criteria, including: area, proportion of coffee to the area, number of coffee farms, and community acceptance of the project. However, there were no special criteria for selecting WSSs, since the four studied systems were all the collective systems in the study area.

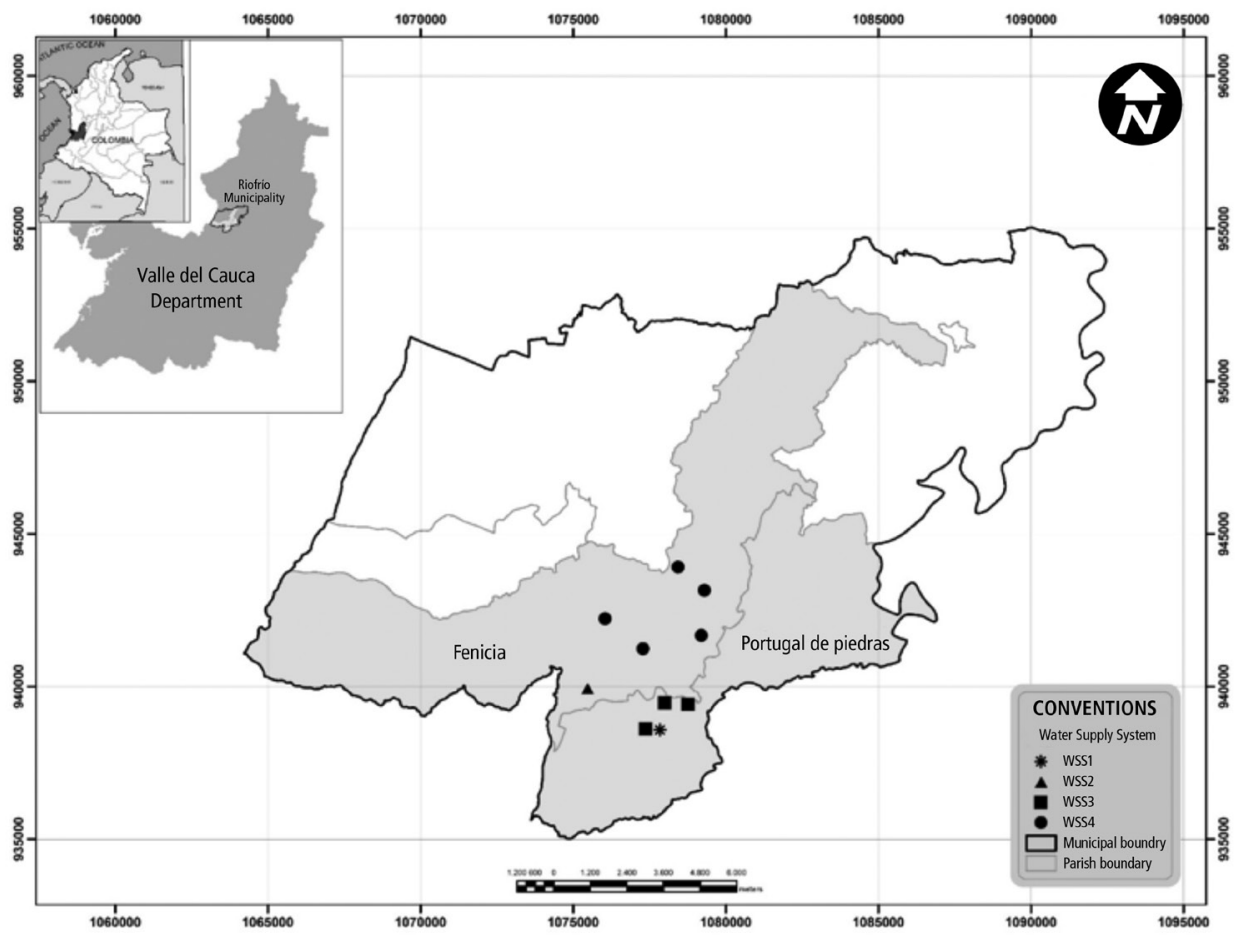

Figure i. Study area and location of the settlements served by the wsss

\subsection{Data collection and analysis}

\subsection{Semi-structured interviews}

Leaders of the four communal wsss were identified using a snowball sampling approach (Robson, 20II), starting with managers contacted through the social worker from DCC. Four semi-structured interviews were carried out with managers from 
the four systems. The interviews addressed issues of history, evolution, organization, compliance of legal requirements, staff, communication, participation, institutional support, Operation and Maintenance (O\&M), commercial and financial aspects, challenges, and community participation.

\subsubsection{Inspections}

Inspection formats included aspects of the most common components identified in the water systems infrastructure. Information was collected through observations focused on the components, their status, and potential risks to water quality (WHO, 2012a, 20I2b). Inspections were carried out with representatives from the water boards and/or systems' caretakers. One inspection was conducted for each system, except for WSS ${ }_{4}$, where leaders participated in the semi-structured interviews but rejected to participate on the inspections and water quality monitoring. Rejection was due to mistrust that could not be overcome since the research was associated to a potential privatization of the system. According to water managers, the local government had made several attempts to privatize WSS . $_{4}$

\subsubsection{Water quality monitoring}

Water samples were collected fortnightly in the communal storage tanks of the studied systems, four times in rainy season (March 2013 - May 2013), and four times in dry season (July 2013 - August 2013), for a total of eight samples per system. As with the inspection, the tanks from the systems were sampled, except for the WSS .

Water analyses were carried out using a DelAgua Portable water testing kit following the manufacturer's procedures (Oxfam-DelAgua, 20I2). Samples were analysed for the parameters suggested by WHO (20I2a, 20I2b): Thermotolerant Coliforms (TTC), $\mathrm{pH}$, and Turbidity. Residual chlorine was not analysed because the three sampled systems did not use chlorine. Only data on microbial quality (TTC) are reported here, since data on $\mathrm{pH}$ and Turbidity were generally within the range of safe water (Turbidity $\leq 5$ Jackson turbidity units -JTL, and $6.5<\mathrm{pH}<8.5$ units) and showed low variability.

\section{Results and discussion}

\section{I. Managerial aspects}

The studied collective systems covered approximately $60 \%$ of the inhabitants in the region. The uncovered population had individual systems. This lack of universal 
coverage is typical of rural regions around the world, where providing adequate water supplies to small, remote and scattered rural communities is a challenge not easily met (Swatuk \& Kgomotso, 2007). Despite the global progress with the MDGs from 2000 to 2015 , the proportion of the population with access to improved sources in the rural areas remain substantially lower, compared to the urban population (Bain, Wright et al., 20I4; WHO \& Unicef, 20I4). In Colombia, low coverage of water in rural areas is partly explained by the low capacities for collecting information, planning, and decision-making in municipalities with low and scattered population, and that receive few transfers from the national government. Furthermore, local governments tend to prioritize water projects in urban areas, due to technical, and political reasons (Asociación Colombiana de Ingeniería Sanitaria y Ambiental [Acodal], 20I4; Departamento Nacional de Planeación [DNP], 20I4).

The number of subscribers in the systems varied in a range from i6 to 560 . In all systems there was some arrangement of community organization responsible for the administration, in line with the general managerial tendency of water provision in rural regions worldwide (Mahmud et al., 2007). In Colombia, it is estimated that around $90 \%$ from all the water providers in rural areas are community-managed (DNP, 20I4), representing about of I2,000 organizations supplying water to approximately seven million people (Bernal et al., 20I4; Smits et al., 20I3). WSS was the only system where the small number of users (I6) and difficulties between them to agree on managerial issues (e.g. tariffs) prevented them to constitute a formal organization. The case of WSS is consistent with the challenges highlighted by van den Broek and Brown (2015) for community management, arguing that rural communities are heterogeneous, there are individualism, differences in wealth, gender, etc. that prevent them to organize effectively around collective action.

In general, the systems fulfilled some legal requirements such as having Statutes and Internal Rules for the Board. However, none of these organizations was registered with the regulatory agency of the State for public services. The managers argued fear to be privatized as the reason to avoid fulfilling this requisite (formalization). The requirement to force community-based organizations to fulfil the same standards of large operators represents a condition of inequality and is one of the factors that prevent them to formalize (Dupuits \& Bernal, 2015). In Colombia, it was estimated that by 2013 only I3\% of the communal organizations were registered with the government (DNP, 20I4).

WSS $_{3}$ and WSS, two from the four systems, also had permissions granted by the Environmental Authority to abstract water, and paid water fees. This case reflects the situation in Colombia, where only $33 \%$ rural providers have the legal right to abstract 
water (DNP, 20I4), and fits the theory of common pool resources which argues users are more likely to follow rules formulated by themselves, in contrast to those that come from government agencies or external elites (Ostrom, 2000).

Table I shows some financial aspects from the organizations. Concerning to financial aspects, tariffs were participatively set in annual system users' assemblies. The tariffs set were low and flat except for wss4, which had differential rates. In this system, when severe damages occurred, resources were obtained from recovery of the default rate. The organization made investments, including replacing pipes, building storage tanks, and improving the office. wss3 managers believed the resources from tariffs were sufficient for O\&M, but scant if major repairs or expansions were needed. To address the lack of resources, the board carried out o\&M activities involving users. For example, gatherings to plant trees at the headwaters, using trees from local species provided by subscribers from their own farms were developed. Additionally, contributions in money and labour were requested to customers when damages occurred. In wss2, managers believed the money raised was enough because no personnel were hired. Resources from tariffs were only for small investments and repairs. In wssi there were no tariffs. Therefore, when damages occurred, conflicts arose among users because there were no mechanisms or resources to deal with problems. Lack of resources for o\&M has been identified as one of the main problems that can lead to failure of community-managed systems (van den Broek \& Brown, 2015). Although the Colombian State recognises subsidies on the water tariffs for the rural population in the lower strata (one, two and three from six categories), these organizations ignored the procedures to materialize access to these resources and translate this benefit to the users.

Financial aspects in these community organizations show that the abilities and resources among the committees were different, being wss4 the most organized system with staff, tariff structures, investments, and revenues. In contrast, wssi had no organization or resources available for undertaking the most basic tasks. Except for wss4, systems did not obtain enough resources to ensure compliance with legal, financial, technical and managerial standards of service provision. Thus, management of water systems is particularly challenging in rural settings since typically resources are insufficient (Strauch \& Almedom, 20II).

Most systems had an inadequate tariff structure, insufficient to cover o\&M costs. The contribution of users to at least the full cost of o\&M through fees is widely recognized as a key factor for sustainable water services (Mandara et al., 2013). The common pool resources theory indicates that the establishment of a fair system in 
TABLE 1 . Financial aspects of community organizations

\begin{tabular}{|c|c|c|c|c|}
\hline AsPECT & wssl & wss2 & wss3 & wss4 \\
\hline Subscribers of the systems (number) & 16 & 27 & 83 & 560 \\
\hline Accounting books & No & Yes & Yes & Yes \\
\hline Billing & No & $\mathrm{No}_{0}$ & $\mathrm{No}$ & Yes \\
\hline Rate (USD\$ / subscriber*month) ${ }^{\mathrm{r}}$ & No & I.6 & I. 3 & $\begin{array}{l}2.6 \text { domestic; } 2.9 \\
\text { domestic }+ \text { small- } \\
\text { scale farming; } 3.7 \\
\text { large-scale farming }\end{array}$ \\
\hline Default rate (months delay) & N.A. & 6 & 3 & 3 \\
\hline Service cuts during the last year (number) & None & $\mathrm{I}$ & None & 23 \\
\hline Subscription fee (USD \$/enrolment) & No & No & 26.6 & 53.1 \\
\hline Expenditures for 20II (USD\$) & No & 267 & 769 & 14,665 \\
\hline Treatment costs ${ }^{\mathrm{I}}$ (USD\$/year) & None & None & None & 3060 \\
\hline Treatment costs per subscriber' (USD $\$$ /year) & 0 & 0 & 0 & 5.46 \\
\hline Annual balance sheet & No & Yes & Yes & Yes \\
\hline Budget & $\mathrm{No}_{\mathrm{O}}$ & $\mathrm{No}_{\mathrm{O}}$ & $\mathrm{No}_{\mathrm{O}}$ & Yes \\
\hline
\end{tabular}

${ }^{1}$ Values for 20I2; N.A.: Not Applicable

Source: Own elaboration

which user inputs are equivalent to the benefits they obtain contribute to system sustainability. In contrast, sustainability is at risk if some users get higher benefits, paying few costs, which could get some users unwilling to follow the system rules (Ostrom, 2000). However, in some of the studied systems poverty, seasonality and unreliability of income, make difficult for people to contribute financially. Even in developed countries, limited revenues due to low population densities, poverty, geographically large service areas, and rate structures which fail to include the full economic costs of the systems make small rural supplies to provide sub-optimal services (Wedgworth et al., 20I4).

Table 2 presents information related to staff availability and their training. WSS ${ }_{1}$ did not have a caretaker. One user usually performed system labours without support from others. In WSS , in the absence of caretaker, the organization established three groups of nine users to perform monthly maintenance tasks. Occasional and emergency repairs were also made under this modality. In WSS, a caretaker was hired under a salary that failed to meet legal standards. The organization was interested in providing training to the caretaker, and to be certified on plumbing by the National Learning Service. However, the caretaker was illiterate. In WSS ${ }_{4}$, the secretary and caretaker had higher levels of education compared to other systemś collaborators. Additionally, they were the only staff from the researched systems, who received the current legal minimum wage and benefits. In all the systems, funds were not available to train personnel. This lack of capacity development may be a possible factor influencing the weaknesses mentioned 
TABLE 2. Personnel and capacities of community organizations

\begin{tabular}{|c|c|c|c|c|}
\hline AsPect & $\mathrm{wSS}_{1}$ & $\mathrm{WSS}_{2}$ & $\mathrm{WSS}_{3}$ & $\mathrm{WSS}_{4}$ \\
\hline $\begin{array}{l}\text { Subscribers of the } \\
\text { systems (number) }\end{array}$ & I6 & 27 & 83 & 560 \\
\hline Employees (number) & $\circ$ & $\circ$ & I (Caretaker) & $\begin{array}{l}2 \text { (Caretaker } \\
\text { and secretary) }\end{array}$ \\
\hline $\begin{array}{l}\text { Salary of employees } \\
\text { (USD/month) }\end{array}$ & ad honours & N.A. & 37.2 & 313 \\
\hline Caretaker educational level & $\begin{array}{c}\text { Incomplete } \\
\text { primary school }\end{array}$ & N.A. & Illiterate & $\begin{array}{l}\text { Complete } \\
\text { secondary school }\end{array}$ \\
\hline Caretaker certification & No & N.A. & No & No \\
\hline Secretary educational level & N.A. & N.A. & N.A. & Incomplete college \\
\hline Staff training & No & No & No & $\begin{array}{l}\text { Yes, but considered } \\
\text { insufficient }\end{array}$ \\
\hline Funds for staff training & No & No & No & $\mathrm{No}$ \\
\hline $\begin{array}{l}\text { Project management } \\
\text { to look for funding }\end{array}$ & No & No & No & No \\
\hline $\begin{array}{l}\text { Availability of inputs, } \\
\text { tools and spare parts for } \\
\text { system's operation }\end{array}$ & Non-existent & $\begin{array}{c}\text { Provided } \\
\text { by the users } \\
\text { when needed }\end{array}$ & Insufficient & Sufficient \\
\hline $\begin{array}{l}\text { Lab equipment } \\
\text { and supplies for } \\
\text { routine analysis }\end{array}$ & Inexistent & Inexistent & Inexistent & Inexistent \\
\hline
\end{tabular}

\section{N.A.: Not Applicable}

Source: Own elaboration

on service provision, since training is a fundamental component of community management (Harvey \& Reed, 2007). However, it has been reported in other rural contexts that communities have received managerial and technical responsibilities without being trained (Mandara et al., 20I3).

\subsection{Technical aspects}

The studied systems where gravity-piped systems, capturing water from protected springs, through a basic collective infrastructure that delivered water to household connections. These systems will be likely considered "improved" according to WHO (2OI2a).

Inspections to the systems helped to identify technical issues related to the infrastructure (Table 3). For most of these issues, water managers were aware and developed solutions, such as headwaters protection and artisanal repairs. However, these repairs were made using only common sense and despite the fact, they allowed continuous operation, they were highly vulnerable to new failures. Other situations were not seen by community organizations as areas for improvement. For example, 
TABLE 3. Technical issues and local solutions

\begin{tabular}{lll}
\hline \multicolumn{1}{c}{ Component } & \multicolumn{1}{c}{ Issues } & \multicolumn{1}{c}{ Local solutions } \\
\hline Source & Landslides & Reforestation initiatives \\
\hline & $\begin{array}{l}\text { Land surrounding the headwaters } \\
\text { was not property from the system }\end{array}$ & $\begin{array}{l}\text { Non-formal agreements } \\
\text { with landowners }\end{array}$ \\
\hline & $\begin{array}{l}\text { Lack of fencing around the headwaters } \\
\text { followed by grazing land }\end{array}$ & Not seen as a problem \\
\hline & $\begin{array}{l}\text { Narrow strips of secondary forest } \\
\text { followed by commercial forest }\end{array}$ & $\begin{array}{l}\text { Verbal agreement between the } \\
\text { community and the company to } \\
\text { allow natural forest to grow in a } \\
\text { strip on either sides of the source }\end{array}$ \\
\hline & $\begin{array}{l}\text { Insufficient water available } \\
\text { during pronounced dry season }\end{array}$ & Shifts on water provision \\
\hline $\begin{array}{l}\text { Wildlife hunting near the headwaters, } \\
\text { removing protective vegetation } \\
\text { and impairing water quality }\end{array}$ & Seen as a problem but unresolved \\
\hline $\begin{array}{l}\text { Water infiltration before the } \\
\text { intake reducing the amount of } \\
\text { water entering to the system }\end{array}$ & $\begin{array}{l}\text { Artisanal reservoir and alternative } \\
\text { pipe to conduct water to the intake }\end{array}$ \\
\hline
\end{tabular}

Accumulation of sediments in the stream bed before the dam and inside the intake chamber due to landslides

Seen as a problem but unresolved in the areas surrounding the intake

\begin{tabular}{lll}
\hline Grit chamber & Lack of tight lid and lock & Installation of a loose metal sheets \\
\hline & Lack of fence & Not seen as a problem \\
\hline & $\begin{array}{l}\text { Lurbulence on the main chamber } \\
\text { with cattle access }\end{array}$ & Not seen as a problem \\
\hline No valves to control flow & Not seen as a problem \\
\hline $\begin{array}{l}\text { Overflow causing problems to the } \\
\text { property that provided permission } \\
\text { to accommodate this structure }\end{array}$ & $\begin{array}{l}\text { Seen as a problem but not local } \\
\text { solution has been implemented }\end{array}$ \\
\hline $\begin{array}{l}\text { Lid without ventilation pipes } \\
\text { or in poor condition }\end{array}$ & Not seen as a problem \\
\hline $\begin{array}{l}\text { Hoses to feed cattle troughs entering the } \\
\text { tank through the inspection chamber }\end{array}$ & Not seen as a problem \\
\hline Lack of fence & Not seen as a problem \\
\hline Collapsed structures & Seen as a problem but unresolved \\
\hline Disinfection system & Disinfection system abandoned & Not seen as a problem \\
\hline Lack of disinfection system & Not seen as a problem \\
\hline Leaks & Seen as a problem but unresolved \\
\hline Lack of purge valves & Not seen as a problem \\
\hline Lack of vent valves & Artisanal perforations \\
\hline Lack of anchorages & Artisanal anchorages \\
\hline
\end{tabular}


the need of fittings and valves for optimum hydraulic operation, and the inadequate functioning of grit chambers. All these systems had more than 40 years use, and after they were built, builders left and the communities faced increasing demands for water with the same infrastructure capacity, and deterioration of units and pipes, due to the lack of resources for investment.

\subsection{Compliance with microbial water quality standards}

Figure 2 shows TTC levels according to system based on WHO categories (WHO, 20I2b). None of the systems met the criteria for microbiologically safe water of $\circ$ $\mathrm{CFU} / \mathrm{rooml}$. These results suggest that even when the subscribers of these systems will be considered people with access to an "improved source", they not necessarily had access to safe water according to WHO standards (WHO, 20I2a). However, currently there are criticisms about the adequacy of the "improved/unimproved" indicator that misses the water quality dimension of access to water (Bain, Wright, et al., 20I4; Grady, Kipkorir, Nguyen, \& Blatchley, 2015; Heitzinger et al., 2015; WHO \& Unicef, 2014); and on the real possibilities of rural systems to meet the $\odot \mathrm{CFU} / \mathrm{I}$ (0oml WHO standard (Domínguez, Torres-López, Restrepo-Tarquino, Paterson, \& Gowing, 2016; Jensen, Jayasinghe, Van Der Hoek, Cairncross, \& Dalsgaard, 2004; Parker et al., 2010). Furthermore, the United Nations post-2015 agenda proposes changing the "improved/ unimproved" indicator for an indicator of "safely managed drinking water services", which includes: use of a water source at the household that reliably delivers enough water to meet domestic needs; fulfil WHO guideline values for E. coli, arsenic and fluoride; and have a risk management plan (WHO \& Unicef, 20I4).

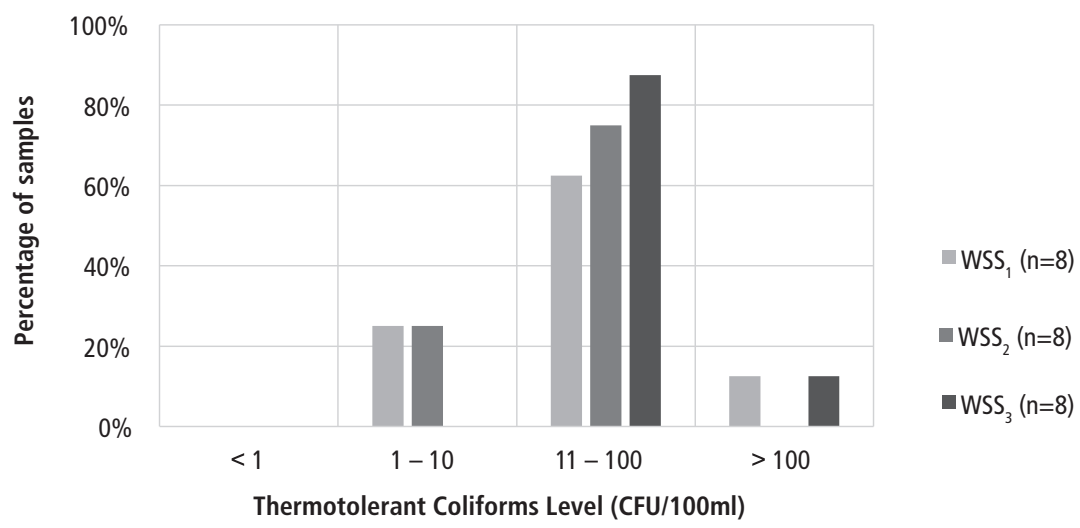

FIgure 2. Percentage of water samples according to TTC level and wSS 
On the other hand, the results of the study highlight the urban-rural gap in access to safe water in Colombia, where data for 2007-20I2 shows that only $4 \mathrm{I} \%$ of samples analysed from rural areas fulfil the microbiological standard compared to $91 \%$ of urban samples (DNP, 20I4). These data are from water quality surveillance by sanitary authorities that only covers $57 \%$ of the rural population (Instituto Nacional de Salud [INS], 20I4; Wright et al., 20I4). This is consistent with systematic reviews that show that rural water supplies in low and middle income countries worldwide present higher levels of contamination compared to urban water supplies (Bain, Cronk, Hossain, et al., 2014).

\subsection{Perceived difficulties for service provision}

Difficulties for service provision expressed by the managers included in WSS : lack of agreement among users to create an organization or join an existent; lack of participation of users in O\&M; and lack of all kind of resources to facilitate service

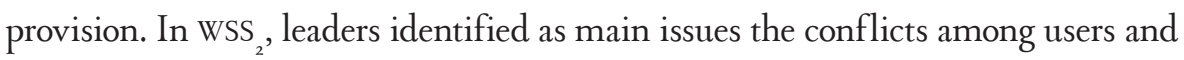
between users and the Board due to insufficient water in dry season that demanded shifts for provision. In WSS, problems were related to: sabotage of systems by some users through valve manipulation during intense dry seasons; crops under agrochemical use upstream the intake; and increase in turbidity in rainy season. In WSS difficulties identified were: dispute with the municipal government to control the system; conflicts with a forestry company, which owned lands at the headwaters; objection of some users to water chlorination; and community complaints for service outages in rainy season due to loss of water quality. Some of these aspects could be categorized among the factors raised in the common pool resources theory, as factors that influence the success of collective action (Ostrom, 2000).

\subsection{Post-construction support}

There was no evidence of investments by the municipal government in any of the systems with the funds local governments in Colombia obtain by law from the national government to invest in water and sanitation. Leaders from WSS, expressed they eventually received support from the local government as materials for emergency repairs, as "payment for political favours". They also received government support to solve conflicts between users, when adjusting tariffs, or during dry season. In Colombia, the provision of economic resources from the government to community organizations through political patronage rather than from transparent and technical processes has been reported by other authors (Murtinho, Eakin, 
López-Carr, \& Hayes, 2013). Other managers indicated support was not requested because they feared to lose control over the systems.

In general, managers wanted training in O\&M, and accounting. However, the local government provided training on job skills for caretakers, but the training was offered to staff from the City Hall with no relation with the rural systems. One of the concerns was the systems' management was given to a joint public-private entity the municipal government tried to constitute. Three Municipal Agreements were issued to create this entity, but the community stopped these initiatives with mass demonstrations. In spite of this, according to the community, the threat persisted. For example, recent regulations from the Ministry of Housing, City and Territory (Decree 1077 of 2015 - [Ministerio de Vivienda, 2015]) have raised questions about whether legally organized communities are still authorized to provide public services in rural areas (Carrasco, 2015).

The sanitary authority (Unidad Ejecutora de Saneamiento [UES]) had relations with WSS $_{3}$ and WSS ${ }_{4}$, systems with the largest number of subscribers in the study, with two main activities: i) water quality monitoring twice a year; and ii) provision of disinfection units and one-year assistance. However, systems' managers felt UES made demands out of reach of small systems with precarious resources. Concerning the disinfection units, after the year of support, facilities provided to WSS were working with monthly costs on chlorine around $\$ 266 \mathrm{US}$, accounting for $20 \%$ of total system costs. In contrast, the disinfection system installed in WSS was abandoned. The disinfection program may be justified on the potential health benefits that could be achieved when access increases from an improved source to an improved source with disinfection (Fewtrell et al., 2005). Although, during the rainy season, water quality can be poor and disinfection can be interfered by turbidity, giving a false sense of security to the community. Therefore, training on administrative and financial aspects, plumbing, O\&M, or undertake investments for the replacement of infrastructure, or the acquisition of land at the headwaters were perhaps more relevant strategies to help these organizations.

Due to the lack of support from the government, NGOs offer some assistance to communities to improve water services (Smits et al., 2013). In the study area, the four systems were built by DCC in the I97os during the coffee boom, being crucial to allow first-time access to water. However, from 1994 DCC reduced investments in water supply with their own funds due to a change on the service provision regulations in Colombia (Ley I42/1994 - "Ley de Servicios Públicos Domicialiarios,” 1994) and the coffee crisis. The current approach of DDC is similar to that most NGOs operating in different parts of the developing world have adopted, which emphasizes on capacity development and strengthening community-based organizations, instead of building 
infrastructure. Despite criticisms on the results from this approach, it is considered more likely to contribute to decentralization (Galvin \& Habib, 2003).

Another NGO in the region was administered by a forestry company with plantations in the area. This NGO led initiatives on: education, income generation, health improvement, and sustainable use of natural resources. However, there was no evidence on projects from this NGO in the region. Conversely, people identified this company as an environmental problem. In many cases, the social investments these organizations undertake aim to mitigate the rejection of local people to the perceived impacts from their operation. For instance, in Australia people tended to view plantations as providing more benefits for owners than positive outcomes for the environment or the broader community (Williams, 2014).

\subsection{Synthesis of the challenges faced by rural community organizations}

In summary, the challenges encountered in these systems are similar to those identified in community-managed organizations around the world: aging infrastructure, difficulty in carrying out replacements, low cost recovery, inadequate human resources, poor staff training and financial management (Harvey \& Reed, 2007; Kayser et al., 2014; Moriarty et al., 2013; Smits et al., 2013; Wedgworth et al., 2014), lack of information for decision making (Roa-García \& Brown, 2009; Smits et al., 2013), inadequate water treatment and water quality monitoring (Kayser et al., 20I4), leakage and microbial contamination; and at a lower level, particularly in dry season in WSS, intermittent supply (Lee \& Schwab, 2005; Moriarty et al., 2013; Smits et al., 2013). In addition, these communities had limited contact or positive relations with the local government. Some of these characteristics were identified by Harvey and Reed (2007), as common causes for the breakdown of community-managed systems.

The community providers in this study area emerged as most water user associations in the Colombian Andes, spontaneously and absent from outside help (Murtinho et al., 20I3). According to Smits et al. (2013), in this country, many small municipalities have not implemented any mechanism to help small organizations in rural areas under their jurisdiction. For them, systems with more than 300 subscribers, treatment plant or pumping station typically received more frequent support. The last statement contrasted with the situation of WSS , which despite of having more than 500 subscribers and treatment plant, had conflicting relations with the government. The absence of political support and inadequate or improper use 
of funds are considered part of the fundamental problems that must be addressed to improve the operation of water supply systems worldwide (Lee \& Schwab, 2005).

This case fits claims of Smits et al. (2013) who argue post-construction support should be an integral part of community management, because the limited number of users prevent achieving economies of scale to generate the revenues to access technical and financial expertise, and these costs are high to be paid via water charges. According to Moriarty et al. (2013), this support is necessary in cases like that reported here, where first-time access has been achieved and the need is sustainable services over time, through schemes in which all aspects of service could be funded. However, the best configuration to provide this support remains unknown (Kayser et al., 20I4). Thus, this is an area where research needs to be developed.

The current Colombian policy for provision of drinking water in rural areas (DNP, 20r4) entitles municipalities to set their support schemes, a contradiction since the same policy recognizes the low capacity of these small municipalities as one of the main causes for the precarious conditions of rural water services. Besides the low capacity and resources, some authors note that corruption at the municipal level can hinder effective post-construction support schemes (van den Broek \& Brown, 2015).

It has been considered that external support can come from multi-level organizations, which may be networks of community providers that besides supporting capacity development around financial, technical and managerial aspects, can gain access to domains of public policy formulation. In Colombia, such an organization is the Association of Community Providers of Water and Sanitation Services (Aquacol), which operates in the southwest of the country. Nevertheless, Aquacol growth has been highly influenced by external support from academia and international donors, and despite its achievements in strengthening community organizations, its financial sustainability in the long term is unclear (Dupuits \& Bernal, 20I5). Furthermore, the support provided by this type of organizations to other community-based organizations could not address necessary aspects of post-construction support in rural communities such as transfer resources for rehabilitation and extension of infrastructure.

On the other hand, the Colombian policy also promotes the operation of urban providers in rural areas and the establishment of regional schemes. This raises questions about the real efforts to strength the more than 12,000 community organizations that for decades have filled the gaps left by the State in rural areas, such as those studied here. According to Dupuits \& Bernal (2015), even when community organizations are recognized under the Colombian law, public policies are not fully oriented to support them. 


\section{Conclusions}

This research analysed managerial, technical, water quality, and post-construction support aspects in four water supply systems operating in an Andean rural area in Colombia. The findings illustrate that small rural water supplies are diverse and vulnerable, for which the capacity of communities to manage these systems needs to be enhanced. Additionally, it appears that the smaller the system, the greater the difficulties to provide the service, therefore, greater external support would be required.

The study contributes an understanding of small rural water supplies, providing evidence for policy formulation that allow strengthen community management organizations, which are crucial to ensure sustainability of water services in rural areas. In particular, the changes on water access and quality indicators proposed on the United Nations post-2015 agenda will represent for governments from development countries such as Colombia to substantially increase their efforts and presence in rural areas. The efforts should be directed towards improving water infrastructure, source protection, monitoring and surveillance coverage, and providing effective post-construction support.

Most of the issues that emerged in relation to the situation of water supply systems in this case study have been part of the international community calls to improve water provision in rural areas. Although there is a large volume of research on individual aspects of rural water supplies, few studies integrate the various dimensions addressed here and combine qualitative and quantitative methods.

Based on the results from this case, some recommendations to government institutions include the need to design on-going post-construction support schemes that include key factors like: training on administration, O\&M, legal aspects, but also mechanisms to transfer resources for rehabilitation and extension of infrastructure, particularly in places where the low number of subscribers, scattering and poverty, prevents achieving economies of scale and collecting enough revenues to bear these major costs. In addition, the mechanisms need to be accessible and transparent, and based on needs assessments, and technical criteria instead of patronage or corruption for a real impact on equity and wellbeing. Research is required on designing and testing these schemes, tailored to the diversity and complexities of small rural water supplies.

The area selected for this research had weak infrastructure on water, health, education and roads; small farms, low population density, and livelihoods based on subsistence farming, which are typical features of rural settings from the Colombian Andes. However, the presence of institutions like DCC is a factor which could make a 
difference on the assets available for this community. Nevertheless, the results from this case fits results from other studies developed in rural areas from Colombia and worldwide as has been shown throughout this work.

\section{References}

Asociación Colombiana de Ingeniería Sanitaria y Ambiental [Acoda] (2014). Propuesta de Acodal para los candidatos a la presidencia período 2015-2019: Plan Estratégico Nacional para Agua Potable y Saneamiento Básico. Documentos técnicos. Retrieved from http://www.acodal.org.co/ plan-estrategico-nacional-para-agua-potable-y-saneamiento-basico/

Bain, R., Cronk, R., Hossain, R., Bonjour, S., Onda, K., Wright, J., et al. (2014). Global assessment of exposure to faecal contamination through drinking water based on a systematic review. Tropical Medicine and International Health, I9 (8), 917-927. doi:I0.IIII/tmi.I2334

Bain, R., Cronk, R., Wright, J., Yang, H., Slaymaker, T., \& Bartram, J. (20I4). Fecal contamination of drinking-water in low- and middle-income countries: A systematic review and meta-analysis. PLoS Medicine, II(5). doi:I0.I37I/journal. pmed.1001644

Bain, R., Wright, J., Christenson, E., \& Bartram, J. (20I4). Rural: Urban inequalities in post 2015 targets and indicators for drinking-water. Science of the Total Environment, 490, 509-513. doi:10.1016/j.scitotenv.2014.05.007

Bakker, K. (2007). The “commons” versus the "commodity": Alter-globalization, anti-privatization and the human right to water in the global south. Antipode, 39(3), 430-455. doi:I0.IIII/j.I467-8330.2007.00534.x

Bambra, C., Gibson, M., Sowden, A., Wright, K., Whitehead, M., \& Petticrew, M. (20I0). Tackling the wider social determinants of health and health inequalities: Evidence from systematic reviews. Journal of Epidemiology and Community Health, 64(4), 284-291. doi:10.1136/jech.2008.082743

Baum, R., Kayser, G., Stauber, C., \& Sobsey, M. (2014). Assessing the microbial quality of improved drinking water sources: Results from the Dominican Republic. American Journal of Tropical Medicine and Hygiene, 9o(I), I2I-I23. doi:I0.4269/ajtmh.13-0380

Bernal, A., Rivas, L., \& Pena, P. (2014). Propuesta de un modelo de co-gestión para los pequeños abastos comunitarios de agua en Colombia. Perfiles Latinoamericanos (43), I59-184. 
Carrasco, W. (2015). Muerte jurídica a la gestión comunitaria del agua en Colombia. Retrieved from http://wash-rural.ning.com/profiles/ blogs/muerte-jur-dica-a-la-gesti-n-comunitaria-del-agua-encolombia?id=5512694\%3ABlogPost\%3A5060I\&page=2\#comments

Colombia, Congreso de la República (1994). Ley de Servicios Públicos Domicialiarios, Ley I42/94. Diario Oficial n. 41433.

Colombia, Ministerio de Vivienda, Ciudad y Territorios (2015). Decreto Único Reglamentario del Sector Vivienda, Cindad y Territorio, Decreto I077 de 2015. Diario Oficial $n^{\circ} 49523$.

Corporación Autónoma Regional del Valle del Cauca [CVC] (20I2). Aplicativo GeoCvC [Cartographer]. Retrieved from http://www.geocvc.co/

Davis, J., Lukacs, H., Jeuland, M., Alvestegui, A., Soto, B., Lizárraga, G., et al. (2008). Sustaining the benefits of rural water supply investments: Experience from Cochabamba and Chuquisaca, Bolivia. Water Resources Research, 44(I2). doi:I0.1029/2007WR006550

De San Miguel, J. A. S. R., Flores, M. M. T., Vilchis, F. L., Tovar, L. A. R., \& Pedraza, A. Y. B. (2015). Community water management in Latin America and the Caribbean: Challenges for Mexico. Journal of Sustainable Development, 8(3), I02-II2. doi:ı.5539/jsd.v8n3pio2

Departamento Nacional de Planeación [DNP] (20I4). Documento Conpes 38ro: Política para el suministro de agua potable y saneamiento básico en la zona rural. Retrieved from http://www.minvivienda.gov.co/conpesagua/3810\%20-\%202014.pdf

Domínguez, I. (20I4). Participatory modelling for bolistic understanding of catchment bealth and buman bealth in andean rural microcatchments, the case of Calabazas (Doctor of Phisolophy). Newcastle University. Retrieved from https://theses.ncl.ac.uk/ dspace/bitstream/10443/2729/I/Dominguez\%20Rivera\%2c\%20I\%202014.pdf

Domínguez, I., Torres-López, W., Restrepo-Tarquino, I., Paterson, C., \& Gowing, J. (20I6). Self-supply as an alternative approach to water access in rural scattered regions: Evidence from a rural microcatchment in Colombia. Ingeniería y Universidad, 20(I). Retrieved from https://www.scopus.com/inward/record. url?eid=2-s2.0-84949528486\&partnerID=40\&md5=6r 8 bd6970ef 89 Icor 3 aeob33f 4386510

Dupuits, É., \& Bernal, A. (2015). Scaling-up water community organizations: The role of inter-communities networks in multi-level water governance. Flux, 99(I), 19-3I. Retrieved from https://www.scopus.com/inward/record. uri eid $=2-s 2.0-84937883456 \&$ partnerID $=40 \& \mathrm{md} 5=60 \mathrm{e} 98522 \mathrm{bc} 5 \mathrm{~d} 65 \mathrm{~b} 833 \mathrm{e} 787 \mathrm{I} 2 \mathrm{fc} 7 \mathrm{c} 3 \mathrm{fo} 4$ 
Fewtrell, L., Kaufmann, R. B., Kay, D., Enanoria, W., Haller, L., \& Colford Jr, J. M. (2005). Water, sanitation, and hygiene interventions to reduce diarrhoea in less developed countries: A systematic review and meta-analysis. Lancet Infectious Diseases, 5(I), 42-52. doi:10.1016/SI473-3099(04)01253-8

Foster, T. (2013). Predictors of sustainability for community-managed handpumps in sub-saharan Africa: Evidence from Liberia, Sierra Leone, and Uganda. Environmental Science and Technology, 47(21), 12037-12046. doi:10.1021/es402086n

Galvin, M., \& Habib, A. (2003). The politics of decentralisation and donor funding in South Africa's rural water sector. Journal of Southern African Studies, 29(4), 865-884. doi:10.1080/0305707032000135860

Grady, C. A., Kipkorir, E. C., Nguyen, K., \& Blatchley, E. R. (2015). Microbial quality of improved drinking water sources: Evidence from western Kenya and southern Vietnam. Journal of Water and Health, 13(2), 607-612. doi:10.2166/ wh.20I4.206

Harvey, P. A., \& Reed, R. A. (2007). Community-managed water supplies in Africa: Sustainable or dispensable? Community Development Journal, 42(3), 365-378. doi:I0.1093/cdj/bsloor

Heitzinger, K., Rocha, C. A., Quick, R. E., Montano, S. M., Tilley, D. H., Mock, C. N., et al. (2015). Improved but not necessarily safe: An assessment of fecal contamination of household drinking water in rural Peru. American Journal of Tropical Medicine and Hygiene, 93(3), 50I-508. doi:10.4269/ajtmh.I4-0802

Hunter, P., Pond, K., Jagals, P., \& Cameron, J. (2009). An assessment of the costs and benefits of interventions aimed at improving rural community water supplies in developed countries. Science of the Total Environment, 407(12), 368I-3685. doi:10.1016/j. scitotenv.2009.03.013

Instituto Nacional de Salud [INs] (2014). Estado de la vigilancia de la calidad del agua para consumo bumano - 20I3. Retrieved from http://www.ins.gov.co/sivicap/Normatividad Jensen, P. K., Jayasinghe, G., van Der Hoek, W., Cairncross, S., \& Dalsgaard, A. (2004). Is there an association between bacteriological drinking water quality and childhood diarrhoea in developing countries? Tropical Medicine and International Health, 9(II), I210-I215. doi:10.1111/j.1365-3156.2004.01329.x

Kayser, G. L., Kayser, G. L., Moomaw, W., Portillo, J. M. O., \& Griffiths, J. K. (2014). Circuit rider post-construction support: Improvements in domestic water quality and system sustainability in El Salvador. Journal of Water Sanitation and Hygiene for Development, 4(3), 460-470. doi:10.2166/washdev.2014.136 
Kochubovski, M. (20II). Water safety in small-scale supplies and new approaches. Journal of Environmental Protection and Ecology, I2(4 A), 20II-20I8

Lee, E. J., \& Schwab, K. J. (2005). Deficiencies in drinking water distribution systems in developing countries. Journal of Water and Health, 3(2), 109-127. Retrieved from http://www.scopus.com/inward/record.url?eid=2-s2.0-27144552783\&partnerID=40\& md5=5352598be95d7edea683933fc98a6ea5

Macharia, P. W., Yillia, P. T., Muia, W. A., Byamukama, D., \& Kreuzinger, N. (2015). Microbial quality of domestic water: Following the contamination chain in a rural township in Kenya. Journal of Water Sanitation and Hygiene for Development, 5(I), 39-49. doi:I0.2166/washdev.20I4.070

Mahmud, S. G., Shamsuddin, S. A. J., Feroze Ahmed, M., Davison, A., Deere, D., \& Howard, G. (2007). Development and implementation of water safety plans for small water supplies in Bangladesh: benefits and lessons learned. Journal of Water and Health, 5(4), 585-597. doi: 10.2166/wh.2007.045

Mandara, C. G., Butijn, C., \& Niehof, A. (2013). Community management and sustainability of rural water facilities in Tanzania. Water Policy, I5(Suppl. 2), 79-I00. doi:10.2166/wp.2013.014

Moriarty, P., Smits, S., Butterworth, J., \& Franceys, R. (2013). Trends in rural water supply: Towards a service delivery approach. Water Alternatives, 6(3), 329-349.

Murtinho, F., Eakin, H., López-Carr, D., \& Hayes, T. M. (20I3). Does external funding help adaptation? Evidence from community-based water management in the Colombian Andes. Environmental Management, 52(5), IIO3-III4. doi:I0.I007/ SO0267-0I3-0I56-Z

Ostrom, E. (2000). Collective action and the evolution of social norms. Journal of Economic Perspectives, I4(3), I37-158. Retrieved from https://www.scopus.com/ inward/record.url?eid=2-s2.0-00007698II\&partnerID=40\&md5=I7I598bfcib3670Icif6 7ra52bo97egf

Oxfam-DelAgua (2012). Oxfam-DelAgua Water testing kit - Users manual. Retrieved from http://www.delagua.org/assets/docs/usermanuals/DeLagua_Brochure_vi_ usermanual.pdf

Parker, A. H., Youlten, R., Dillon, M., Nussbaumer, T., Carter, R. C., Tyrrel, S. F., \& Webster, J. (2010). An assessment of microbiological water quality of six water source categories in north-east Uganda. Journal of Water and Health, 8(3), 550-560. doi:10.2166/wh.2010.128

Roa-García, C., \& Brown, S. (2009). Assessing water use and quality through youth participatory research in a rural Andean watershed. Journal of Environmental 
Management, 90(I0), 3040-3047. Retrieved from http://www.scopus.com/inward/record. url?eid=2-\$2.0-67651183617\&partnerID=40\&md5=90319facf50a9icca67c80f580c87ea7

Robson, C. (20II). Real world research: a resource for users of social research methods in applied settings (3rd ed.). Sussex, UK: John Wiley \& Sons.

Smits, S., Rojas, J., \& Tamayo, P. (20I3). The impact of support to community-based rural water service providers: Evidence from Colombia. Water Alternatives, 6(3), 384-404.

Strauch, A. M., \& Almedom, A. M. (20II). Traditional water resource management and water quality in rural Tanzania. Human Ecology, 39(I), 93-I06. doi:10.1007/ SIO745-OII-9376-O

Swatuk, L. A., \& Kgomotso, P. K. (2007). The challenges of supplying water to small, scattered communities in the Lower Okavango Basin (LOB), Ngamiland, Botswana: An evaluation of government policy and performance. Physics and Chemistry of the Earth, 32(15-18), I264-I274. doi:I0.1016/j.pce.2007.07.036

Van den Broek, M., \& Brown, J. (2015). Blueprint for breakdown? Community Based Management of rural groundwater in Uganda. Geoforum, 67, 51-63. doi:10.1016/j. geoforum.2015.10.009

Wedgworth, J. C., Brown, J., Johnson, P., Olson, J. B., Elliott, M., Foreh, R., \& Stauber, C. E. (20I4). Associations between perceptions of drinking water service delivery and measured drinking water quality in rural Alabama. International Journal of Environmental Research and Public Health, II(7), 7376-7392. doi: 10.3390/ ijerphiı0707376

Whittington, D., Davis, J., Prokopy, L., Komives, K., Thorsten, R., Lukacs, H., et al. (2009). How well is the demand-driven, community management model for rural water supply systems doing? Evidence from Bolivia, Peru and Ghana. Water Policy, II(6), 696-7I8. doi:I0.2I66/wp.2009.310

World Health Organization [WHO] (20I2a). Guidelines for drinking-water quality (20II). Retrieved from http://www.who.int/water_sanitation_health/publications/20II/ dwq_chapters/en/

World Health Organization [WHO] (2012b). Rapid assessment of drinking-water quality: a bandbook for implementation. Retrieved from http://www.who.int/ water_sanitation_health/publications/20I2/rapid_assessment/en/ World Health Organization [wHo] \& United Nations Children's Fund [Unicef] (2014). Progress on drinking water and sanitation - 2014 update. Retrieved from http:// www.unicef.org/gambia/Progress_on_drinking_water_and_sanitation_20I4_ update.pdf 
Williams, K. (20I4). Public acceptance of plantation forestry: Implications for policy and practice in Australian rural landscape. Land Use Policy, 38, 346-354. doi:I0.1016/j.landusepol.2013.II.023

Wright, J., Liu, J., Bain, R., Perez, A., Crocker, J., Bartram, J., \& Gundry, S. (20I4). Water quality laboratories in Colombia: A gis-based study of urban and rural accessibility. Science of the Total Environment, 485-48(I), 643-652. doi: 10.1016/j. scitotenv.2014.03.127

Yin, R. (2014). Case study research: Design and methods ( $5^{\text {th }}$ ed.). Thousands Oaks, California: Sage Publications. 